Databases, Revenues, \& Repertory: The French Stage Online, 16801793 - Databases, Revenues, \& Repertory: The French Stage Online, 1680-1793

The Strange Career of Voltaire, Bestselling

Playwright of EighteenthCentury France

Lauren R. Clay

Published on: Oct 08, 2020

License: Creative Commons Attribution 4.0 International License (CC-BY 4.0). 
To most readers, it would seem impossible that it could have become necessary to save François-Marie Arouet, better known as Voltaire, from the condescension of posterity.- During his lifetime, according

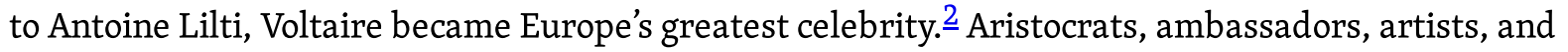
men and women of letters made pilgrimages to his chateau at Ferney to meet or even just catch a glimpse of a living genius. $\underline{3}$ By the 1760 s, his fame was such that an array of Voltaire merchandise, including portraits, silhouettes, small busts, and intimate engravings purporting to reveal his private life, were marketed to curious and eager fans. ${ }^{4}$ His triumphal return to Paris in 1778 after a thirty-year absence threw the capital into paroxysms of excitement, culminating in his ceremonial crowning at the Comédie-Française. Even after his death, Voltaire loomed larger than life. The project to establish a Panthéon where France's "grands hommes" would be honored by "la patrie reconnaissante" was conceived with Voltaire in mind. He was the first man of letters interred there, by order of the National Assembly, in July $1791 . \underline{5}$ Voltaire remains a foundational figure in the French literary canon and in the French national imagination, and his works are widely read today.

Yet it cannot be denied that in the past century Voltaire's theatrical reputation has fallen on hard times. Theater specialists, literary scholars, and cultural historians, to be sure, agree that Voltaire was the most celebrated playwright of the eighteenth century as well as one of the most prolific. From the unprecedented success of his first tragedy $\mathbb{E}$ dipe in 1718 through to the apotheosis of the aged philosophe at a performance of Irène in the spring of 1778, he was the leading French playwright. Henri Lagrave, noting that eight of Voltaire's plays were among the Comédie-Française's greatest successes of the first half of the eighteenth century, concluded: "Ce n'est pas une surprise que Voltaire soit le grand homme de la Comédie-Française.” artine de Rougemont concurred that Voltaire "domine et entraîne tous les poètes de son temps." $\mathrm{XVIII}^{\mathrm{e}}$ siècle le grand carrefour de toutes les recherches théâtrales, le grand inspirateur de toutes les initiatives." $\underline{8}$

Over the course of the nineteenth century, however, Voltaire's theatrical reputation collapsed. His plays declined so sharply in popularity that by the 1850 s performances had become rare. 9 Despite the fact that a small but growing number of French directors have recently reintroduced audiences to Voltaire theatrical works including L'Écossaise and Le Droit du seigneur, only two plays written by Voltaire have been staged by the Comédie-Française since the turn of the twentieth century: Zaïre, last produced in 1936, and L'Orphelin de la Chine, revived briefly after a 130-year hiatus, in 1965. 10 The troupe, and seemingly the public, abandoned him.

Critical assessments of Voltaire's dramatic legacy have been correspondingly bleak. As early as 1895, the critic Émile Faguet observed that “Les tragédies de Voltaire ont été, depuis 1730 jusqu’en 1820 
environ, considérées, même par les ennemis de Voltaire, comme ce qu'il avait fait de plus beau, et, depuis 1820 jusquà nos jours, presque comme ce qu'il a fait de plus négligeable."1ㅡ Today, when his plays are contrasted implicitly or explicitly with those by Racine and Corneille, it is to Voltaire's detriment. Jay Caplan observes that "Voltaire's often melodramatic attempts at tragedy. . . bore implicit witness to the decline of the genre." $\underline{12}$ Other critics have gone further. In his classic essay The Death of Tragedy, George Steiner derided Voltaire's works as “cold, declamatory pieces in which the forms and rules of neo-classicism were observed with servile pedantry." 13 One scholar declared Voltaire's theatrical oeuvre, with the sole exception of Zaïre, to be un-performable. $\underline{14}$

At the same time, among literary scholars and the lay public alike, Voltaire-the-playwright has been overshadowed by Voltaire-the-philosophe, Voltaire-the-essayist, and Voltaire-the-human-rightscrusader. Today, Candide and the Lettres philosophiques are among his best-known works. His plays have all but dropped out of the literary canon. $\underline{15}$ Specialists have not been immune to shifting aesthetic preferences and the reframing of Voltaire's image to highlight other aspects of his remarkable career. In the recent Cambridge Companion to Voltaire, for example, Voltaire's theatrical career is almost eclipsed by his virtuosity in other genres. $\underline{16}$ Geoffrey Turnovsky's biographical essay mentions the breakthrough success of $\mathscr{E}$ dipe, but largely passes over the rest of his career as a playwright. "Who constituted Voltaire's public?" Turnovsky asks, responding that it was "a public formed by his writing, whether his letters, satires, poems, histories, stories or pamphlets." 17 The absence of his plays-and by implication his unprecedentedly large domestic and international theater public - in this list raises interesting questions about Voltaire's legacy and the ways the man and his oeuvre have been remembered.

How do we explain the strange career of the best-selling playwright whose works defined an era, and yet today are hardly performed and rarely read? How should we understand the meteoric rise and no less precipitous collapse of this crucial element of Voltaire's literary reputation? Moreover, how do we reconcile Voltaire's unmatched ability to pack in spectators at the Comédie-Française and to move his eighteenth-century public to tears with the widely shared critical assessment that his work constituted a chapter in the "decline" and "death" of tragedy?

This essay uses new resources in the digital humanities to track changing responses to Voltaire's repertory by audiences and critics across the eighteenth and early nineteenth centuries. In doing so, it exposes the sharp contrast between the exuberant contemporary reception of Voltaire's repertory by the eighteenth-century paying public with his less than glorious "theatrical afterlife." The concept of a "theatrical afterlife" was introduced by Mechele Leon, who has argued that the reputations of national authors such as Molière are inherently unstable, reformulated over time by successive generations. Although critics invoke concepts such as "aesthetic genius" or "timeless appeal" to explain why certain works or playwrights achieve enduring recognition, the reality, she writes, is more complex. Literary 
reputations according to Leon are "made, reassessed, stored, lost, and stolen." $\underline{18}$ As a contested "lieu de mémoire," the history of Voltaire-the-playwright stands to reveal as much about French cultural politics as about the multifaceted genius of the Sage of Ferney. $\underline{19}$

To explore the paradox of Voltaire's unstable afterlife, this essay is divided into three parts. Part one uses newly available data on box-office receipts to bring to light the unequalled draw of works by Voltaire among eighteen-century theater spectators at the Comédie-Française when compared with other playwrights, living or dead. Part two considers the reasons behind Voltaire's exceptional commercial success. The final section surveys the changing critical interpretations of Voltaire's theatrical repertory by analyzing histories of French literature published between the Revolution and 1840, by which time the Comédie-Française had already dropped all but a very few of Voltaire's works from its active repertory.

To explain the collapse of Voltaire's theatrical appeal, scholars have traditionally offered two explanations. The first points to the triumph of Romanticism after 1830. Seeking to break from (what they described as) the shackles of Neoclassicism, Victor Hugo and other Romantic playwrights explicitly set their work against that of Voltaire, the most prominent writer within the still-dominant cultural model. $\frac{20}{}$ Rejecting the unities of place and time, they succeeded in profoundly changing aesthetic tastes, opening the door for greater naturalism on stage and establishing the primacy of imagination in art. According to Marvin Carlson, Voltaire's theatrical repertory "lies firmly on the other side of that great divide created in western literature by romanticism."21 Afterwards, these scholars argue, Voltaire's works no longer spoke to contemporary audiences in the same way. $\underline{22}$

A second group locates Voltaire's tragic repertory within the evolution of the genre of tragedy, which is portrayed as reaching its height in the seventeenth century in the works of Jean Racine and Pierre Corneille. These critics evaluate Voltaire's work and influence within a narrative of the decline and eventual death of tragedy, often characterized as "paralyzed by the models of the Grand Siècle." $\underline{23}$ At best, Voltaire's innovations in setting and themes, character development, and use of spectacle in his plays are characterized as offering life support to a terminally ill genre. At worst, Voltaire's efforts actually hastened tragedy's demise. $\underline{24}$

This essay contributes to these conversations in two ways. First, repertory and financial data clearly demonstrate that the contemporaries who packed into the Comédie-Française on evenings when Voltaire's works were being staged were by no means aware that tragedy was in its death throes. In fact, beginning in the 1730s and continuing through to the Revolution, Voltaire emerges as an unprecedented box office success. He outsold all other playwrights-including even Molière-with a wave of popular hits that included the single bestselling play of his era, Zaïr. $\frac{25}{\text { The question of }}$ 
Voltaire's appeal, both critical and popular, looks different in light of this evidence, which invites new questions about the ways that theatrical taste was formed and spectatorship cultivated.

Second, taking into account his eighteenth-century dominance, Voltaire's critical collapse over the course of the nineteenth century appears all the more striking. Following Leon, this essay argues that assessments of literary significance hinged on more than aesthetic considerations. For nineteenthcentury literary critics confronting the contested legacies of the French Revolution, Voltaire emerged as France's most politically polarizing author. In the pages of their literary surveys, scholars and men of letters struggled to reconcile Voltaire's status as an already-acknowledged 'great man' and literary giant with their personal ambivalence towards an individual increasingly depicted as personally responsible for the French Revolution, including its violent de-Christianization campaigns. At a time when histories of French literature written for teachers, students, and the general public portrayed Voltaire in extreme terms - "personne na mieux servi la cause du prince des ténèbres que Voltaire" $\underline{26}$ one such work reads-Revolutionary and post-Revolutionary politics, we find, played a defining and yet little-acknowledged role in shaping Voltaire's unstable dramatic legacy.

\section{Contemporary Reception}

As we consider the reception of Voltaire's works, it is crucial to document the unprecedented scope of his success during this lifetime. The Comédie-Française Registers Project ( $\underline{C F R})$ offers new insight into the repertory trends of France's royal dramatic theater company by providing researchers with exceptionally detailed and comprehensive data about the roughly 34,000 performances staged between 1680 and 1793. When earlier generations of scholars studied the repertory of the royal troupe, they meticulously counted performances using the original manuscript registers, housed in the archives of the Comédie-Française, or microfilm copies. Alexandre Joannidès described the timeconsuming nature of this important work: "Rien pour l'auteur nétait plus laborieux à achever, rien ne sera pour les lettrés plus utile à consulter que ce vaste répertoire où pas une oeuvre, pas un à-propos n'est oublié et qui a pris plusieurs années à celui dont la tâche est aujourd'hui achevée."27 The new $\underline{\text { CFRP }}$ database makes it possible to undertake a wide array of research queries quickly and accurately, while sitting at a computer anywhere in the world. Crucially, for the first time it pairs performance history data with box office receipts and an array of other variables, enabling scholars to gain a more accurate and nuanced portrait of the relative popularity of playwrights and their works over time. The database makes it especially easy to track and compare bestsellers, a phenomenon as valuable to literary and theater scholars as to cultural, social, and intellectual historians.

Prior repertory studies of the Comédie-Française have effectively downplayed the full scope of Voltaire's popularity, largely because of methodological constraints. Two of the best-known studies, those by Henri Lagrave and Joannidès, used the total number of performances of a playwright's works as the principal gauge of success. (Lagrave uses this to project spectatorship.) By excluding box office 
revenue as a factor, they effectively underreport the popular draw of the works of Voltaire. This phenomenon is magnified by the ways they structured their studies. Lagrave's analysis of Paris theater audiences from 1715 to 1750 , for example, considers the repertories of seventeenth-century and eighteenth-century playwrights separately. Lagrave's "repertory" chapter considers the works of Molière, Racine and Corneille, mentioning Voltaire only in passing. Voltaire's works are discussed later in the book, in a section devoted to the successes of the era in which his career is compared to that of other living authors. Moreover, Lagrave's study covers just over half of Voltaire's career, stopping well before his popularity peaked..$\underline{28}$ Joannidès's reference work, in contrast, compiles the repertory of the Comédie-Française, playwright by playwright for the much longer chronological scope of 1680 to

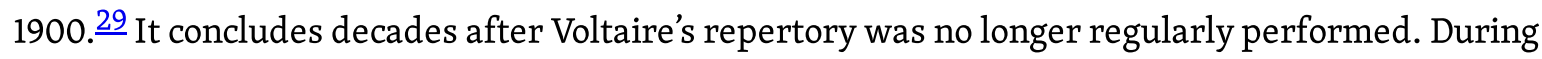
these 220 years, Joannidès found, Voltaire ranked respectably as the fifth-most-performed playwright at the Comédie-Française. Still, the 3,950 performances of Voltaire plays during this time frame are markedly fewer than the 6,270 performances by Jean Racine, the 5,262 by Jean-François Regnard, and the 4,717 by Pierre Corneille. They do not even approach the 20,290 performances of works by Molière. $\frac{30}{}$ The founder of the Comédie-Française and the "father" of the modern French dramatic tradition, Molière has long provided the measure against which all other French playwrights are compared. These studies - and many others - confirm this expectation by shining a spotlight on Molière.

It is here that the CFRP database reveals surprising trends. When the performance history of Voltaire is directly compared to that of Racine and Corneille, for the majority of the eighteenth century, Voltaire comes out well ahead of France's most acclaimed tragic playwrights. Specifically, beginning in the 1740s and continuing through the 1780 s, Voltaire consistently bested these dramatists, as well as other popular writers such as Dancourt (Florent Carton), Philippe Néricault Destouches, Marc-Antoine Legrand, and Jean-François Regnard, according to three different metrics: the number of performance days by the royal troupe, the average earnings of evenings when their works were staged, and the total income of evenings they were performed. $\underline{31}$ Already in the 1730 s, despite the fact that his repertory was still relatively small, he out-performed Corneille, with 170 performance days to Corneille's 139. That decade he still came in behind Racine's 254. Beginning in the prolific 1740s, however, Voltaire surpassed the total number of performance days by Racine, on a decade-by-decade basis. He remained more frequently performed than either of these authors throughout the Old Regime and the early Revolution. [Fig. 1] On the measure of box office income, the pattern is similar. [Fig. 2] By the 1730s, Voltaire evenings surpassed those featuring Racine and Corneille works in average and total earnings. Evenings featuring his repertory more than doubled their box office receipts during the 1740 s and tripled them during the 1760 s. 


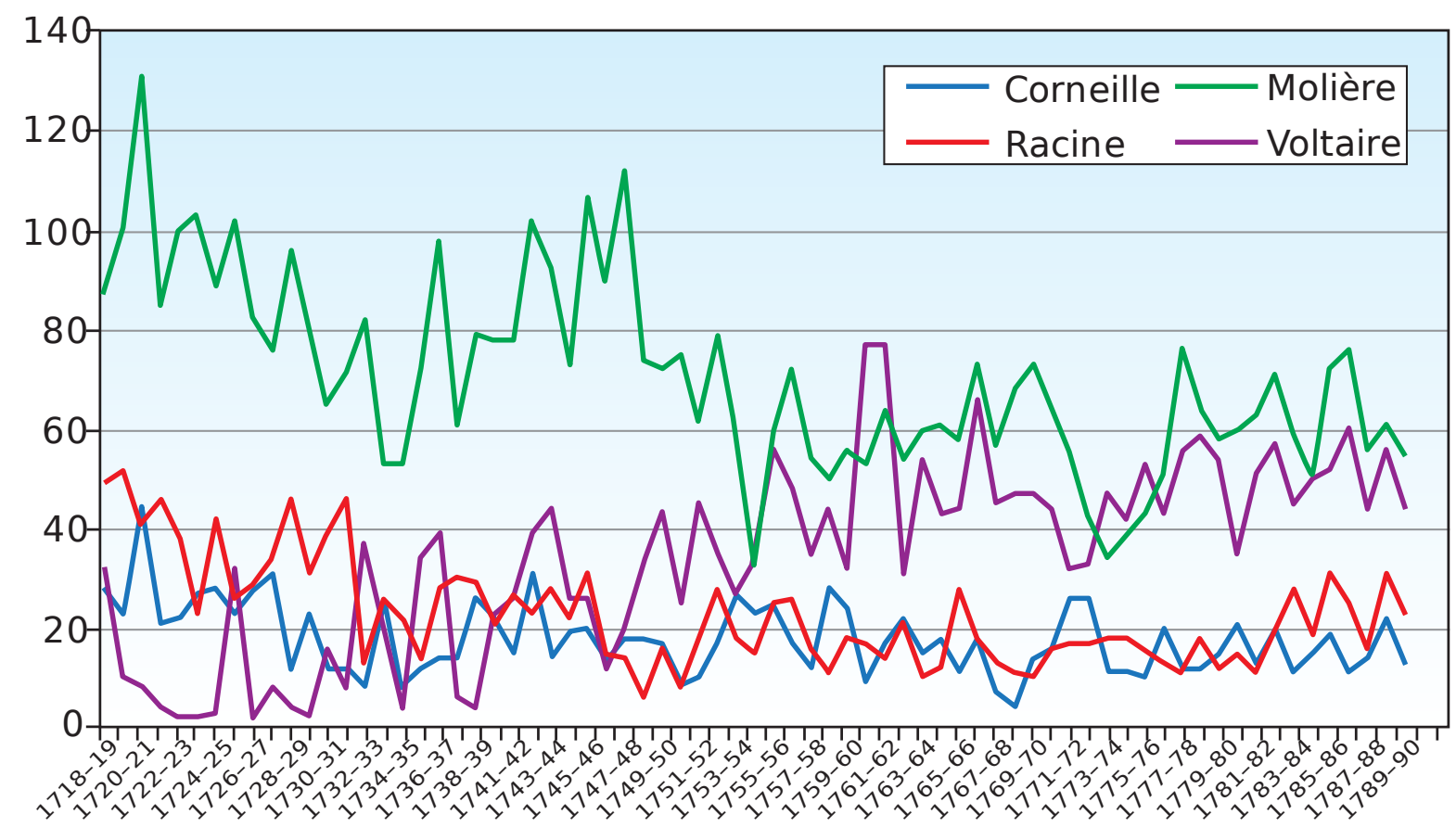

Figure 1 . Total number of evenings featuring an author's plays, per season.

It is when Voltaire is compared directly with Molière that the full scope of his popularity is revealed. Although Molière remained on average the most frequently performed playwright at the ComédieFrançaise throughout the eighteenth century, Voltaire came in an increasingly close second. During several seasons (1760-61, 1761-62, 1773-74, 1774-75, and 1775-76), works by Voltaire were actually staged on more evenings than those by Molière. $\underline{32}$ [Fig. 1]

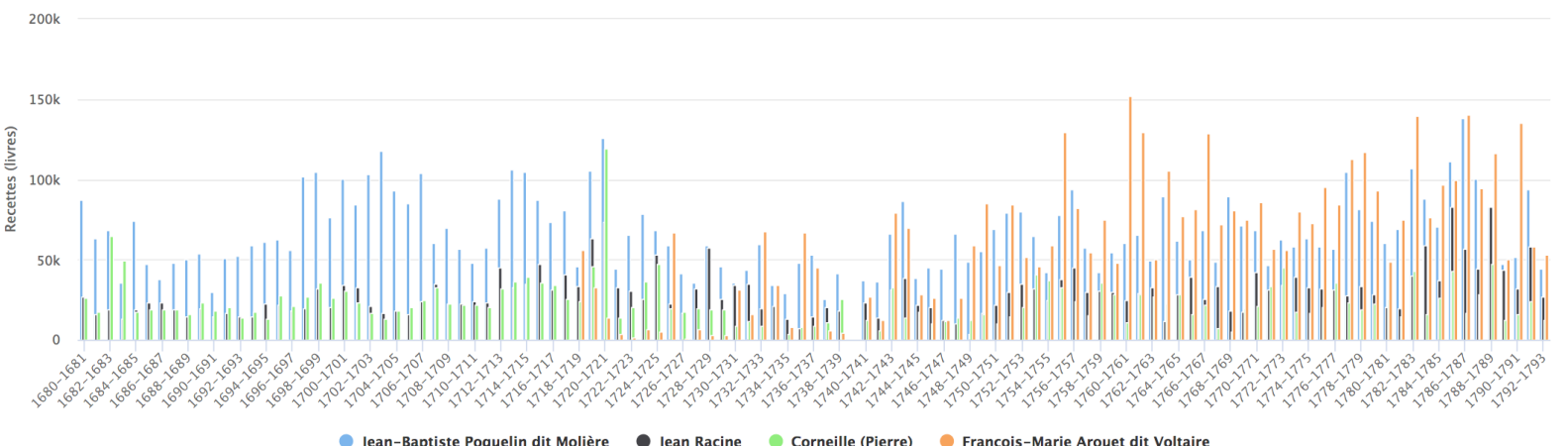

Figure 2. Gross box office revenue for performance evenings, by author. 
In box office sales, the data surprises. From the 1750s through until the early 1790s, on a decade-bydecade basis the total revenue from ticket sales for evenings featuring Voltaire was consistently higher than for evenings featuring works by Molière - or any other playwright, for that matter-despite the fact that Molière was played more often. [Fig. 2] During the 1750s, spectators spent nearly eighty thousand livres more to attend Voltaire evenings than Molière evenings: 688,538.50 livres versus $609,941.50$ livres. During the 1760s, when Voltaire was at the peak of his popularity, the difference was much greater. Over the course of that decade, Voltaire's nights outsold Molière's by more than 320,000 livres: 927,978.75 livres to 606,546.50 livres. (To provide a comparison, that decade the third-place Dancourt's evenings brought in less than half as much as Voltaire's in ticket sales. The next highestearning living playwright, Bernard-Joseph Saurin, sold entries worth roughly one-sixth as much as Voltaire's.) $\stackrel{33}{ }$ Voltaire's dominance of the market, unaffected by his death in 1778 , continued through the 1780 s and into the early Revolution. Even Pierre-Augustin Caron de Beaumarchais' runaway success during the 1780s, Le Mariage de Figaro, did not unseat Voltaire, who outsold Beaumarchais that decade by roughly thirty percent. $\underline{34}$

Voltaire's popularity only increases when we focus on the first play performed in an evening. Although we cannot be certain which plays, performers, or other motivations brought individual spectators to the theater, the first work typically constituted the main attraction of the evening, usually a longer five-act work followed by a shorter comedy. When tragedies were on the bill, they almost always led off the evening. When only the first play is considered, the database demonstrates that starting in the 1750s, Voltaire's repertory led the playbill considerably more often than Molière's; by the end of the 1792-93 season, a total of 270 more times. Moreover, for the seasons stretching from 1720 to 1793 , Voltaire-anchored evenings, collectively, brought in twice the box office revenue of those by Molière. $\frac{35}{3}$ Voltaire, in sum, emerges as the runaway bestselling author of his era. Over the course of his career, between 1718 and 1793, his evenings earned more than 4.48 million livres at the box office, more than any other author. $\underline{36}$ [Fig. 3] 


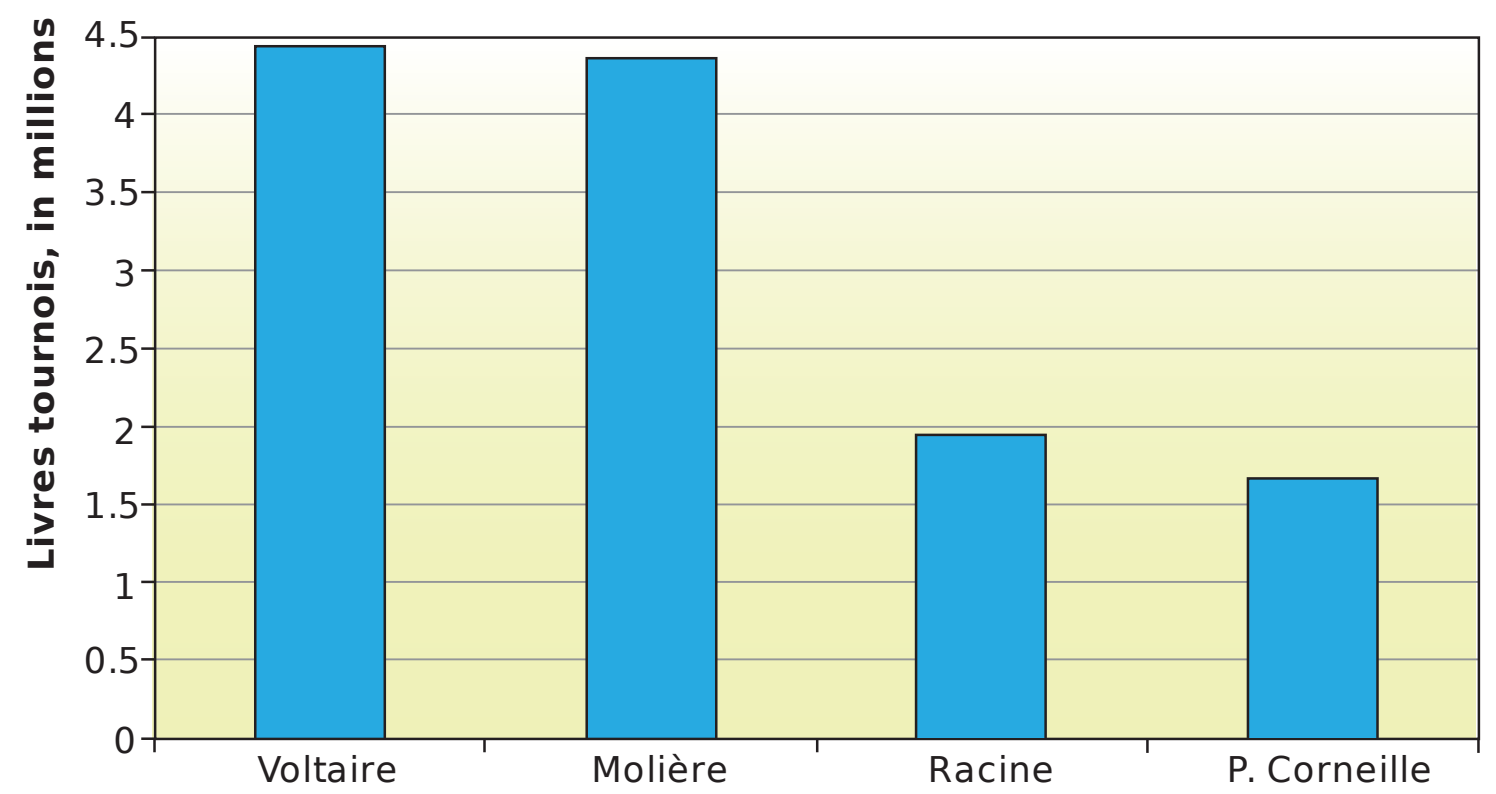

Figure 3. Total earnings by author for Voltaire, Molière, Racine and P. Corneille,
1718-1789.

How was this possible? When Voltaire was still a young man, he flashed brilliantly onto the literary scene with his tragedy $\mathbb{E}$ dipe, which debuted on November 30 , 1718. It quickly became the mostperformed new tragedy in the history of the Comédie-Française, with forty-two stagings in just two years. $\frac{37}{}$ This breakthrough is often credited as establishing Voltaire's reputation as a man of letters, and this is undoubtedly true. It is no less true, however, that Voltaire propelled himself to a position of dominance on the French dramatic stage through decades of creative production marked by continued and close engagement with both the Comédiens du roi and with his growing national and international public.

During the course of his career, Voltaire introduced no fewer than twenty-nine different plays onto the royal stage, which compares favorably with the twenty-six works by Molière, nineteen by Corneille, and twelve by Racine that had entered into the troupe's repertory. [Fig. 4] 
Databases, Revenues, \& Repertory: The French Stage Online, 1680-1793

- Databases, Revenues, \& Repertory: The French Stage Online, 1680-

1793
The Strange Career of Voltaire, Bestselling Playwright of Eighteenth-

Century France

\begin{tabular}{|c|c|c|c|c|c|c|}
\hline Titre & Recettes (livres) - & Représentatio... & Date de la Premiè... & Jouée e... & Jouée e... & Genre \\
\hline Zaïre & 504357 & 229 & $1732-08-13$ & 228 & 1 & tragédie \\
\hline Mérope & 422534 & 207 & $1743-02-20$ & 204 & 3 & tragédie \\
\hline Alzire ou les Améric... & 414915 & 239 & $1736-01-27$ & 236 & 3 & tragédie \\
\hline Tancrède & 381420 & 174 & $1760-09-03$ & 169 & 5 & tragédie \\
\hline Sémiramis & 334137 & 164 & $1748-08-29$ & 162 & 2 & tragédie \\
\hline Nanine ou le Préjug... & 317127 & 195 & $1749-06-16$ & 51 & 144 & comédie \\
\hline Fanatisme ou Maho... & 302876 & 159 & $1742-08-09$ & 158 & 1 & tragédie \\
\hline Orphelin de la Chin... & 287175 & 137 & $1755-08-20$ & 133 & 4 & tragédie \\
\hline CEdipe & 252165 & 188 & $1718-11-18$ & 187 & 1 & tragédie \\
\hline Café ou l'Écossaise... & 203110 & 132 & $1760-07-26$ & 131 & 1 & comédie \\
\hline Adélaïde du Guesclin & 189392 & 109 & $1734-01-18$ & 107 & 2 & tragédie \\
\hline Enfant prodigue ou ... & 183956 & 292 & $1736-10-10$ & 292 & 0 & comédie \\
\hline Brutus & 168488 & 106 & $1730-12-11$ & 106 & 0 & tragédie \\
\hline Mort de César (La) & 94537 & 39 & $1743-08-29$ & 35 & 4 & tragédie \\
\hline Hérode et Mariamn... & 93508 & 58 & $1724-03-06$ & 58 & 0 & tragédie \\
\hline Oreste & 87711 & 43 & $1750-01-12$ & 41 & 2 & tragédie \\
\hline Rome sauvée ou Ca... & 49721 & 22 & $1752-02-24$ & 21 & 1 & tragédie \\
\hline Amélie ou le Duc de... & 46614 & 27 & $1752-08-17$ & 27 & 0 & tragédie \\
\hline Olympie & 39551 & 16 & 1764-03-17 & 16 & 0 & tragédie \\
\hline Indiscret (L') & 34142 & 23 & $1725-08-18$ & 0 & 23 & comédie \\
\hline Artémire & 30257 & 8 & $1720-02-15$ & 8 & 0 & tragédie \\
\hline Écueil du sage (L') /... & 27929 & 14 & $1762-01-18$ & 8 & 6 & comédie \\
\hline Zulime & 25930 & 18 & $1740-06-08$ & 18 & 0 & tragédie \\
\hline Irène & 21005 & 7 & $1778-03-16$ & 7 & 0 & tragédie \\
\hline Ériphile & 20262 & 12 & $1732-03-07$ & 12 & 0 & tragédie \\
\hline Scythes (Les) & 18757 & 9 & 1767-03-26 & 9 & 0 & tragédie \\
\hline Sophonisbe & 7849 & 4 & $1774-01-15$ & 4 & 0 & tragédie \\
\hline Agathocle & 6915 & 4 & $1779-05-31$ & 4 & 0 & tragédie \\
\hline Octave et le jeune $\mathrm{P} . .$. & 2511 & 1 & $1764-07-05$ & 1 & 0 & tragédie \\
\hline
\end{tabular}

Figure 4. List of Voltaire plays in Comédie-Française repertory.

CFRP Discovery Tool. Can be sorted by receipts, \# of performances, or alphabetically by title. 
After Edipe, Voltaire debuted Artémire in 1720, Mariamne (later re-written as Hérode et Mariamne) in 1724 and L'Indiscret in 1725. During the 1730s and 40s, Voltaire wrote for the stage at an ever more rapid clip. The Comédiens du roi debuted Brutus in 1730 and Ériphile and Zaïre in 1732. These were followed by Adelaïde du Guesclin (1734), Alzire (1736), and L'Enfant prodigue (1736). The following decade he created Zulime (1740), Mahomet ou le Fanatisme (1741), Mérope (1743), La Mort de César (1743), Sémiramis (1748), and Nanine (1749). During the 1750s, the Comédie-Française performed Voltaire's Oreste (1750), Amélie (1752), Rome sauvée (1752), and L'Orphelin de la Chine (1755). Another six works debuted in the 1760s, including Tancrède (1760), Le Café ou L'Écossaise (1760), L'Écueil du sage ou Le Droit du seigneur (1762), Octave et le Jeune Pompée ou le Triumvirat (1764), Olympie (1764), and Les Scythes (1767). Voltaire's final works included Sophonisbe (1774) and Irène (1778), and finally Agathocle (1779), which debuted after his death. $\underline{38}$ Over the course of the six decades during which he wrote for the stage, the prolific Voltaire offered the royal actors a large and varied repertory to choose from and a stream of novelties to draw in curious crowds.

The fact that Voltaire remained the premier tragic playwright of the era, with no serious competitors, boosted the number of performances that he received and his total earnings. $\frac{39}{}$ This was the case because tragedy consistently drew in larger crowds that included spectators willing to spend more for their seats. On average, evenings featuring a tragedy significantly out-earned all-comedy showings at the box office. $\underline{40}$ At the same time, Voltaire's polyvalence set him apart. Few authors successfully crossed genres with hits in both comedy and tragedy. His most frequently performed work during the Old Regime and early Revolution was a comedy: L'Enfant prodigue was performed 292 times up through 1793. He enjoyed other comic successes. Nanine ou le Préjugé vaincu, with 195 showings, was performed more frequently than many of his tragedies. The Comédiens du roi staged Le Café ou l'Écossaise 132 times, and Adélaïde du Guesclin 109 times. $\underline{41}$

If Voltaire became the favorite go-to tragic playwright of the Comédiens du roi, the reason his works were placed on the program so frequently is no secret: he made the troupe money, and lots of it. To be sure, not all of these works were successful. Even Voltaire penned his share of flops. Six of his plays received fewer than ten performances before closing permanently; and four more were performed fewer than twenty times. Yet thirteen Voltaire works received more than 100 performances. $\frac{42}{}$ Decade after decade he scored regular hits, with his box office draw increasing alongside his growing celebrity. Although $\mathbb{E}$ dipe debuted at the royal theater in late 1718, during the 1720 s it became the sixteenth highest earner of the decade. $\frac{43}{}$ The 1730 s marked a breakthrough for with Zaïre reaching number two and Alzire number three at the box office. In the 1740s, Mérope was the top selling ticket of the decade. During the 1750s, Voltaire's L'Orphelin de la Chine was the decade's top seller, with those evenings bringing in more than 103,000 livres. Zaïre meanwhile took fourth place with slightly more than 98,000 livres in nightly sales. During the height of his popularity, in the 1760s, Tancrède emerged 
as number one with nearly 160,000 livres at the box office. Le CaféouL'Écossaise came in at second place, with more than 113,000 livres. That decade, Voltaire's success was buoyed by the popularity of Mérope and Nanine, in eighth and ninth place respectively, with ticket revenues of roughly 78,000 livres. During the 1770s, three of Voltaire's plays ranked among the decade's top ten earners: Tancrède reached number three, Alzire number five, and Mahomet number six. Zaïre, according to this metric, was the highest earning play of the era 1700-1789. $\underline{44}$

In time, the royal troupe came to rely on Voltaire. Between 1740 and 1790, the sales for Voltaire performances comprised, on a decade-by-decade average, between sixteen and twenty-six percent of the total box office income of the Comédie-Française. During blockbuster seasons like 1760-61, 1761-62, and 1766-67, this "Voltaire effect" provided approximately one-third of daily ticket sale income for the year. $\underline{45}$ [Fig. 5$]$

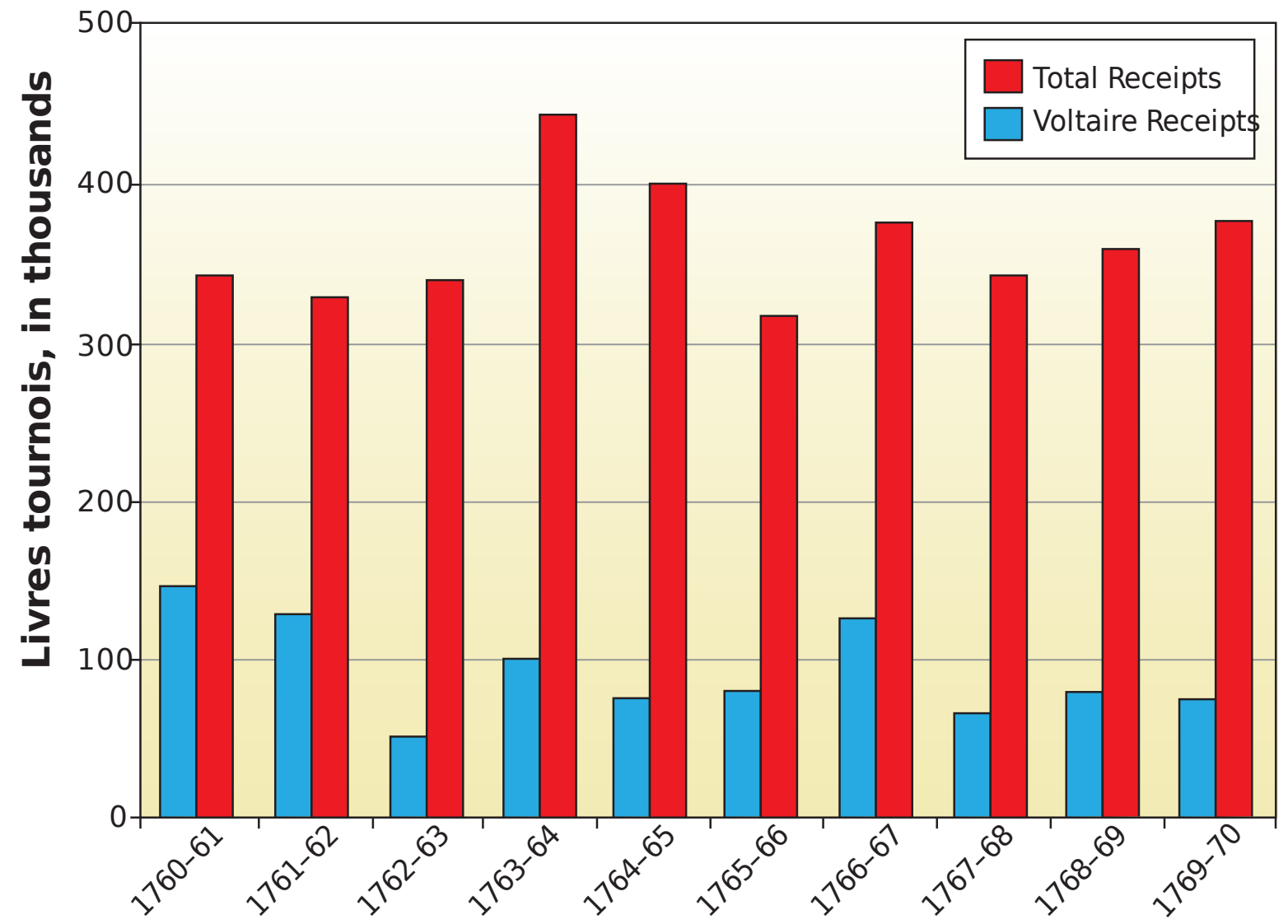

Seasons 


\section{Unlocking the Secret of Voltaire's Success}

The data provided by the CFRP raises the question: what accounts for Voltaire's unparalleled box office success? This question merits a more extensive analysis than can be afforded in this chapter.

Scholarship on Voltaire's theatrical career by Marvin Carlson, Henry Carrington Lancaster, and JeanJacques Olivier, however, suggests that Voltaire's popularity was founded upon an especially close and productive relationship with the Comédiens du roi and a continuous effort to engage the public by any means necessary.

For any author aspiring to achieve honor, recognition and eventually fame and fortune through the eighteenth-century stage, the first order of business was to get one's works accepted by the royal dramatic theater in Paris. The second was to have these plays placed on the performance schedule, ideally as often as possible. The actors and actresses who were members of the royal company selected their own repertory. They were notoriously opinionated and demanding judges whose considerations included not only the literary merits of a work but also the interests of the company and, frequently, of their personal careers. $\frac{46}{}$ Beginning with his very first tragedy, Voltaire learned to take the opinions of the actors seriously, writing for them and even to an extent with them. An impatient author, Voltaire was known for composing his plays at a rapid speed in passionate fits of writing. He famously drafted entire five-act tragedies in verse within a matter of weeks and even at times, allegedly, within a matter of days. When this first draft was complete, however, he would continue to revise itsometimes very extensively-in dialogue with his closest readers, the royal actors, and the public. This practice began out of necessary when the troupe initially rejected $\mathcal{E}$ dipe, accepting it only after he made some substantial changes (and after two of the most vociferous critics, who just happened to hold important roles in Corneille's Edipe, had retired and died, respectively.) He respected the opinions of the actors. When the troupe raised concerns about Mérope, he corresponded with Mlle Quinault to assure her that the draft had been "prodigieusement corrigée et limée." $\underline{47}$ Not infrequently, rewriting continued after opening night, as Voltaire responded to audience reactions. $\underline{48}$ From the mid-1750s through to the 1770s, Voltaire invited leading tragic actors of the troupe to visit him at Les Délices and later at Ferney to perform drafts of plays that he was composing. In this way, he invited them to participate in the creative process. L'Orphelin de la Chine provides one example of this process. Comédie-Française scholar Jean-Jacques Olivier writes that Voltaire drafted the play, sought advice from readers, rewrote it, invited the actor Henri-Louis Lekain to perform it, made additional revisions, and then sent this third version to the troupe via his close friend the comte d'Argental. $\underline{49}$ Voltaire's intimate relationships with the leading members of the troupe spanned many decades, from his friendship with Adrienne Lecouvreur in the 1720s through his close collaborations in the 1750s and 60s with Lekain and Mlle Clairon. Voltaire can be credited with “discovering” Lekain: he trained him as 
an actor prior to his debut with the troupe, and continued to mentor him for decades. For the tragic actors in the Comédie-Française, Voltaire crafted roles that accentuated their talents, offering up a steady stream of star vehicles. He also recognized that the performers were critical for a play's popular success. When L'Orphelin de la Chine debuted in Paris, he praised Clairon's work and acknowledged to others that "C'est Mlle Clairon qui établit tout le succès de la pièce." $\underline{50}$ Clairon and Lekain made their mark starring in Voltaire tragedies such as L'Orphelin de la Chine and Tancrède not only in Paris but also through long and profitable tours of provincial playhouses. $\underline{51}$

A gifted actor, Voltaire took an active role in interpreting his plays for the troupe. According to Olivier, “il est peu de poètes qui aient apporté à l'exécution de leurs œuvres autant de soins que Voltaire. Lorsque ce dernier écrivait une tragédie, il réglait en avance les mouvements de chaque personnage, la diction de chaque tirade." $\underline{52}$ When Voltaire was in Paris, he attended rehearsals of new works, coaching the actors to realize his vision. During the many years when he was living away from Paris, he provided d'Argental with extensive written instructions and sent him to rehearsals in his stead. Even as Voltaire embraced the conventions of classical tragedy as established by Racine and Corneille, including the use of alexandrine verse and the three unities (a single locale, a single day, and a single plotline), he advocated reforms in performance style, costuming, and stage sets. $\underline{53}$ He is often credited with igniting the successful campaign to have the stage of the Comédie-Française cleared of the wealthy spectators who paid to sit as close as possible to the actors. This offered greater space, freedom, and quiet for the performers while offering the audience a less distracting view and the ability to immerse itself in the performance more completely. $\underline{54}$

Whereas Corneille and Racine operated within a cultural system defined by patronage, writing principally for the king and other powerful patrons, Voltaire, writing for the stage decades later, could not afford not to write for the Paris public. $\underline{55}$ It was the spectators, after all, who decided the reception and ultimate fate of a work. From time to time, Voltaire himself suffered the sting of failure. Explaining certain plot changes made to Mariamne, which had closed after a disastrous first evening, for the revised Mariamne et Hérode, Voltaire wrote in the preface to the play: "Mais je nai voulu combattre en rien le goût du Public. C'est pour lui, \& non pour moi que j'écris: Ce sont ses sentimens \& non les miens que je dois suivre." 56 Later, still smarting from the recent failure of Ériphile, he told one friend about the new work that he was composing, Zaïre: "Tout le monde me reproche ici que je ne mets point d'amour dans mes pièces. Ils en auront cette fois-ci, je vous jure, et ce ne sera pas de la galanterie. Je veux qu'il n'y ait rien de si turc, de si chrétien, de si amoureux, de si tendre, de si furieux que ce que je versifie à présent pour leur plaire." That same day, he explained in a letter to another, “je tâcherai de jeter dans cet ouvrage tout ce que la religion chrétienne semble avoir de plus pathétique, et de plus intéressant, et tout ce que l'amour a de plus tendre et de plus cruel." $\underline{57}$ When writing Adelaïde 
du Guesclin, he described his efforts to move the audience: “j'ai fourré le plus que j'ai pu d'amour, de jalousie, de fureur, de bienséance, de probité et de grandeur d’âme." $\underline{58}$

Even as Voltaire sought to impress with enormous casts, spectacular sets, and plots featuring betrayal, murder, and ghosts, he did not hesitate to harness controversy to draw in the crowds. Already in his very first tragedy, the young Voltaire had set out to rival the Edipes of playwrights no less distinguished than Sophocles and Corneille. In 1760, reaching the peak of his fame, he attacked his literary adversaries openly onstage. When the playwright Charles Palissot de Montenoy ridiculed Diderot and Rousseau in Les Philosophes, Voltaire, at the urging of the royal actors, revised his manuscript Le Café ou l'Écossaise for performance. In the play, he satirized one of Palissot's mentors, the Counter-Enlightenment journalist Élie-Catherine Fréron in a character named Frelon (wasp), while Fréron's journal L’Année littéraire became LÂne littéraire (the literary jackass). The royal actors encouraged such rivalries because they drove sales. $\underline{59}$ When necessary, Voltaire was not above buying audience support. For the opening night of Sémiramis in 1748, he purchased four hundred tickets and distributed them, building his own cheering section. $\underline{60}$ Outside the playhouse, the controversy provoked by Voltaire's public crusades on behalf of the family of Jean Calas and others, Pierre Frantz argues, stoked his theatrical celebrity. $\frac{61}{}$

Voltaire's dominance of the stage was such that his works became a principal point of theatrical reference. Isabelle Degauque has found that between 1719 and 1761, at least thirty-nine different parodies of works by Voltaire were performed at the Foire Saint-Germain, the Comédie-Italienne, the Opéra-Comique, and the Boulevard theaters. $\underline{62}$ Voltaire detested being the target of satire, but he could do nothing to stop a phenomenon that only increased his renown among larger and more socially diverse audiences. His repertory sparked interest far beyond the borders of France. $\frac{63}{}$ During the eighteenth century, Rahul Markovits has shown, more than two dozen European courts and cities established their own French-language acting troupes. On these stages, Voltaire served as the living emblem of French theater culture, with his works featuring prominently in surviving repertories. $\underline{64}$ His influence crossed the Channel as well. Sixteen Voltaire plays were reworked for the English stage, performed at theaters including Drury Lane, Covent Garden, and Lincoln's Fields. $\underline{65}$ "For nearly a hundred years," Harold Bruce noted, "adaptations of his plays were on the boards of London theatres." $\underline{66}$

In sum, the eighteenth-century spectators who packed houses in Paris, Lyon, London, Vienna, and elsewhere did not share the disdain for Voltaire's plays shared by many later nineteenth- and twentieth-century critics. Contemporary critics, too, were unaware that, in the words of Steiner, "the dramatic imagination" had "collapsed" and that tragedy was incompatible with the spirit of the Enlightenment. Nor did they recognize that Voltaire was, in the words of one scholar, 
“progressivement décalé par rapport au goût du siècle." $\underline{67}$ Parisian spectators may have been drawn to Voltaire debuts because they were curious to see what the celebrated and provocative author produced next. His works remained so prominent in the repertory of the royal theater, however, and generated unparalleled ticket sales for so many decades because audiences opened their pocketbooks and came back again and again.

Critics have often faulted Voltaire for innovating within the constraints of the neoclassical tradition, rather than daring to break with convention to invent an entirely new theatrical genre. From the standpoint of ticket sales, however, Voltaire's strategy matches perfectly with what consumer psychologists, sales strategists, and cultural critics have "discovered" about aesthetics and taste during the twentieth century, namely that customers are torn between the appeal of novelty and their discomfort with the alien. $\frac{68}{}$ For those wooing customers, too much innovation involves considerable risk because it raises fear of the unknown. If the public as a general rule is disinclined to spend free time and hard-earned money to experience something that is too radically new, that is because some degree of familiarity-of recognition-is necessary to touch people. It is an element of pleasure. If today this principle informs commercial cultural production in many domains, Voltaire can be considered a master avant la lettre. He presented a stream of new themes, sets, and costumes, ideas, and intense emotions within a classical framework that both the royal actors and the Parisian public seem to have found pleasingly predictable. $\frac{69}{}$

\section{Cultural Politics in Post-Revolutionary France: "la faute à Voltaire"}

The CFRP database records continue only through 1793, when the Comédie-Française was dissolved, a victim of the radicalizing Revolution. Using Joannidès's research as a guide, however, we can trace the outlines of Voltaire performance history into the nineteenth century by looking at the number of stagings. Whereas the Comédie-Française performed Voltaire works on average fifty evenings a year during the 1780 s and early 1790 s, this number declined when the troupe was reconstituted in $1799 . \underline{70}$ With twelve of his works still active in the troupe's repertory, he received an average of roughly 33 performances a year for the first three decades of the nineteenth century. Although Voltaire still featured among the most frequently performed playwrights, he fell somewhat in the ranks, surpassed by Molière, Racine, and others. Then, in 1830, annual performances of Voltaire plays plunged into single digits. Although there was some recovery during the 1840 s, beginning in the later 1850 s Voltaire was dropped from the repertory for years at a time. After mid-century, only a handful of works remained active in the troupe's repertory and these were seldom performed. $\underline{71}$ Over a century before the final performance of L'Orphelin de la Chine in the mid-twentieth century, Voltaire-the-playwright, for all practical purposes, was already dead. $\underline{72}$ 
What happened? How did France's most popular playwright fall so far, so fast? As a political and intellectual figure, Voltaire's cultural prominence continued undimmed during the Restoration. According to Martyn Lyons, his collected works were leading bestsellers from 1816-1830, with multiple editions saturating the market. His plays outsold those of Corneille. $\underline{73}$ The French Revolution, however, had significantly reframed perceptions of the Sage of Ferney, amplifying the controversy surrounding his legacy while also attaching it even more strongly to his theatrical works. The revolutionaries had explicitly adopted Voltaire, like Rousseau, as a forefather of the Revolution. In 1790, Mirabeau had selected Voltaire's La Mort de César and Brutus for performance at the first Festival of the Federation. In 1793, the Committee of Public Safety had ordered Brutus, which it recognized as a "patriotic" work, to be performed for free on a weekly basis. $\frac{74}{}$ At the theaters that replaced the then-defunct former royal theater (the Théâtre de la République, the Théâtre de l'Égalité, and the Théâtre Feydeau), Brutus, described by one scholar as "la pièce emblématique du républicanisme pur et dur," was the most frequently performed Voltaire work of the decade 1789-99. When all revolutionary Parisian stages are taken into account for this era, although his comedy Nanine took first place as his most-performed work, Brutus, significantly, came in second. $\underline{75}$

Even as Revolutionaries "pantheonized" Voltaire as a national political-literary hero, parading his remains with elaborate ceremony from the Bastille to the former church of Saint-Geneviève before depositing them there 0 , counter-revolutionaries excoriated him. $\underline{76}$ Extreme anti-Voltaire rhetoric was certainly not new. As Darrin McMahon has shown, as early as the 1750s clergy and professors at the Sorbonne began explicitly accusing the philosophes in general and Voltaire in particular of undermining the monarchy and seeking to destroy religion in France. A work depicting Voltaire as the devil's minion appeared in 1760; it was reprinted thirty times before 1789. During the Revolution and Napoleonic era, however, Counter-Enlightenment Catholic reactionaries amplified and popularized these discourses, arguing that Voltaire had sowed the seeds for the destruction of the Catholic Church and indeed of France itself. $\underline{77}$

During the Restoration, Catholic missionaries singled out Voltaire as a fanatic of heresy. They regularly organized burnings of Voltaire's works across France. Meanwhile, "liberals used Voltaire as a badge of their anticlerical resistance against the excesses of post-revolutionary bigotry." $\underline{78}$ Stephen Bird describes Voltaire's nineteenth-century legacy as "explosive." “[N]o one symbolised the division of France into two warring camps more acutely than Voltaire," he explains. "[T]o side against him was to pine for a return to an imagined golden age of pre-revolutionary certainties enshrined in the principles of unfettered absolutism in politics and religion; to side with him was to embrace a brave new world of freedom and equality." $\underline{79}$

Survey histories of French literature published during the late Revolution, Restoration, and early July Monarchy reveal critical clues concerning the collapse of Voltaire's theatrical reputation. $\frac{80}{E l e v e n}$ such 
works in the collection of the Bibliothèque nationale de France, written for students, teachers, and fellow critics, address the eighteenth century at some length. As a set, these texts demonstrate the difficulties contemporaries faced during the early 1800s in grappling with Voltaire's larger-than-life status in the world of theater at a time when he served as a lightning rod for political, religious, and cultural controversy. The extent to which religious politics and assessments of Voltaire's political and moral legacy entered into French literary history is striking. Struggling on the page with their assessments of the man and his works, literary scholars and critics were not immune to the polarizing cultural politics that presented the Revolution as "la faute à Voltaire."

These works can be divided into three categories. On one extreme, we find three partisans of Voltaire, including the playwrights Jean-François de La Harpe and Marie-Joseph Chénier. They depicted Voltaire unhesitatingly as one of the greatest tragedians of all time, keeping company with Racine and Corneille. Writing during the Revolution, La Harpe, a veritable disciple of Voltaire's who lived with him at Ferney for a time and even corrected drafts of his plays, extolled his theatrical writing. "Voltaire," he wrote, "fut décoré des mêmes titres que le grand Racine." The title role in Edipe, he wrote, was better developed than in the Greek original. Zaïre was "la plus touchante de toutes les tragédies qui existent," with a leading character "digne d’être comparé aux plus beaux de Corneille." $\underline{82}$ Chénier similarly praised Voltaire in his 1816 study. He argued that "La seule tragédie présente trois modèles illustres. Corneille eut un génie sublime: il sut créer; il est grand. Racine eut un talent admirable: il sut embellir; il est parfait. Voltaire eut un esprit supérieur: il étendit les routes de l'art; il est vaste." $\underline{83}$ A third text by Pierre Hennequin argued that although the loss of Racine and Corneille appeared insurmountable, at just nineteen Voltaire proved they had a successor. $\underline{84}$

In sharp contrast, writing during the late 1830s, after cultural battle lines had hardened, the critic Auguste Desprez depicted the eighteenth century as a shameful era of literary and moral decadence led by “deux hommes qui créèrent le philosophisme, c'est-à-dire qui systématisèrent les attaques que déjà l'on dirigeait contre toutes les garanties sociales, contre toutes les autorités protectrices; Voltaire et Rousseau." The author concedes that "leur talent que l'on ne peut sérieusement contester, rendirent aux lettres un peu de l'éclat qu'elles avaient perdu..." Still, he charges that they used this talent to pour out

... leurs poisons sur la société et les distiller pour ainsi dire goutte à goutte dans leurs ouvrages; la France accueillit leurs funestes leçons sans défiance, et de toutes parts, la moralité publique, l'esprit religieux s'affaiblirent; l'on en vint pas à pas jusqu'à mépriser la religion, l'autorité, et tout finit par les périlleuses expériences de 1789, par les horribles catastrophes de 1793.

Desprez ranked Voltaire's tragedies immediately after those of Racine and Corneille, but he added that Voltaire was by no means their equal as a poet and that he lacked their grandeur. At times, he damned 
with faint praise, explaining that when Voltaire was not dispensing philosophy or attacking kings and priests, he usually wrote "suitable" dialogue. In the eyes of this Catholic reactionary who was also the editor of the Almanach du clergé de France, Voltaire was guilty of abusing his talent. He was the "grand démolisseur," who prostituted

... son âme et sa plume aux plus vils mensonges, aux plus hideuses calomnies, contre ce qu'il y a de plus sacré et de plus inviolable dans la conscience des peuples, des familles et des individus, je veux dire contre la foi religieuse de leurs pères, et les institutions fondamentales de leur patrie.

Voltaire unleashed the "torrent qui allait tout détruire." 15

The majority of these studies - seven works published between 1813 and 1838 - fell on a spectrum in between these extremes. Each identified Voltaire as a giant of his century. Many, however, also pointed out shortcomings. Several criticized Voltaire's didactic approach that many argue led him to use his plays to present philosophical or political lessons. One scholar argued that his works could not equal those of Racine because they merely imitated him. $\frac{86}{}$ Another observed that Voltaire aspired toand achieved - third place in classical tragedy, whereas he might have taken first place in a new genre of his own creation. .87 A third mused about what Voltaire might have become - the role he might have played -if he had employed his talents differently. $\underline{88}$

Tellingly, most reveal the strains of commenting on such a politically charged figure. Did praising Voltaire's verse mean condoning or even endorsing "sa haine de la religion"? $\underline{89}$ Even the liberal-minded H.-B. Aigre noted critically that "il porta au dernier point son incrédulité en matière de religion, et il est la principale cause de la fausse interprétation donnée de nos jours au titre de philosophe, que croient pouvoir s'arroger tous ceux qui affectent de ne croire à rien". $\underline{90}$ Although Abel-François Villemain addressed the philosophes more broadly, Voltaire was clearly foremost in his mind when he wrote,

Le parti philosophique fit un peu comme une armée d'invasion qui entre dans un pays sous prétexte de l'affranchir, et qui brûle, pille, saccage, détruit. Ainsi, dans le champ de la morale, ces écrivains qui ne voulaient que ruiner quelques préjugés. . finirent par attaquer la spiritualité de lâme, la réalité de la conscience, la liberté de la pensée humaine, et Dieu même. $\underline{1}$

To Émile Vanderburch, ethical concerns about the man applied to the writer as well: "On ne pouvait prendre pour guide un homme qui montrait en riant le précipice, sans indiquer de route pour l'éviter." 22 From the Restoration through the 1830s, Voltaire-the-playwright remained inextricably associated with the Revolution that had so conspicuously laid claim to his legacy-and that remained for many a painful rupture. The near-unanimity of this interpretation had elevated it to the status of fact. $\underline{93}$ 
It was not critics, of course, but the actors of the Comédie-Française who decided to discontinue performing Voltaire's plays. $\underline{94}$ One commentator noted that the troupe permanently retired a strikingly large number of historically popular works between 1830 and 1850: "aussi voit-on entre ces dates une épidémie décimer le répertoire." Voltaire was a principal target of these "extinctions," but he was far from alone. In contrast, the members dropped relatively few plays between 1870 and 1920. $\underline{95}$ Their motivations remain uncertain. As acting styles evolved and new works entered the repertory, did these plays simply no longer make the cut? Did this culling of their active theatrical heritage seem necessary because staple Old Regime favorites had become inaccessible and therefore unpopular? Given that Voltaire's plays remained bestsellers through the 1820s and continued to be described as works of great achievement even by his ardent enemies through the 1830s, this seems less likely to apply to his oeuvre. Did the members of the troupe share the increasingly critical literary opinion about Voltaire? Were they fatigued by the cultural politics that had made Voltaire a stand-in for the radical Revolution? We may not find definitive answers to these questions. What we do know is that it would have been all but impossible to dissociate these mid-nineteenth-century repertory decisions from the polemic surrounding Voltaire. And those decisions definitely altered France's theatrical canon.

\section{Conclusion}

Unlike most once-popular playwrights, Voltaire's repertory was not quietly retired, only to fade into obscurity. By the late nineteenth century, the fact that his plays were so seldom performed-having been dropped out of the Comédie-Française's active performance canon-seems to have made it even easier to disparage the qualities of his once-celebrated theatrical works. Yet the imprint of the Revolution on his theatrical afterlife did not dim. Throughout the nineteenth century, his plays continued to spark bitter disputes among critics that were as much political as they were literary.

Already in 1813, Amable-Guillaume-Prosper de Barante had noted the impossibility of evaluating Voltaire's theatrical works impartially:

Leur mérite a été cent fois agité et remis en problème. Presque toujours accueillis avec enthousiasme par le public, ils ont rencontré en même temps des détracteurs obstinés, et l'esprit de parti a sans cesse présidé au jugement qui en était porté. Un demi-siècle s'est écoulé, et la réputation de Voltaire est encore, comme le cadavre de Patrocle, disputée entre deux partis animés l'un contre l'autre. $\underline{96}$

More than eighty years later, the literary scholar Henri Lion affirmed that the impassioned battle over Voltaire's theatrical legacy was hardly over. 
On a discuté, on discute, et on discutera toujours sur la valeur des tragédies de Voltaire, car toujours la passion s'en mêle. On ne peut parler de Voltaire poète tragique sans se souvenir ou de l'homme ou du polémiste. . . tout ce qui concerne Voltaire est encore tout moderne, tout chaud en quelque sorte et tout scabreux. . $\underline{97}$

Even as the Dreyfus Affair roiled late nineteenth-century France, aesthetic assessments of Voltaire's qualities as a playwright were interspersed with commentary alternately praising or condemning the man "qui a tué chez nous la religion." $\underline{98}$

The strange career of Voltaire highlights the challenge inherent in the critical project of distinguishing "great" plays from "bad" plays when opinions have varied so dramatically over time. Voltaire's theatrical works, we find, meant dramatically different things to different people at different times. Should the judgements of nineteenth-century critics aghast at Voltaire's virulent anticlericalism or more recent scholars' diagnoses of literary stagnation and decline be viewed as more accurate than the opinions of hundreds of thousands of eighteenth-century fans, who expressed their enthusiasm for Voltaire's plays with their pocketbooks? The new data provided by the CFRP database frees us to study the historical Voltaire on his own terms and within his own context by providing access to an era, perhaps difficult to conceive today, when for Parisians Voltaire was the hottest ticket in town.

\section{Footnotes}

1. The author would like to thank Jeffrey Ravel, Sylvaine Guyot, Pierre Frantz, Nicholas Cronk, and the anonymous reviewer for their comments and suggestions on this research. Kate Devine provided helpful assistance with research in Paris. This essay is dedicated to Nicholas Cronk, friend, mentor, and Voltaire scholar extraordinaire. $\triangleq$

2. Antoine Lilti, Figures publiques: L'invention de la célébrité 1750-1850 (Paris: Fayard, 2014), $28 . \Xi$

3. Jean-Claude Bonnet, Naissance du Panthéon: Essai sur le culte des grands hommes (Paris: Fayard, 1998), 226-232.

4. Lilti, Figures publiques, $30-32 . \bullet$

5. Bonnet, Naissance du Panthéon, 266-267. $\subseteq$

6. Henri Lagrave, Le Théâtre et le public à Paris de 1715 à 1750 (Paris: Klincksieck, 1972), 605. Based on the data provided by the Comédie-Française Registers Project (CFRP), Voltaire was the most prolific playwright of his era writing for the royal theater. The 29 Voltaire plays performed by the ComédieFrançaise were surpassed by the 58 works of Dancourt (Florent Carton) that the troupe performed. Dancourt retired in 1718, the very year that Voltaire debuted with the theater. $\subseteq$ 
7. Martine de Rougemont, La Vie théâtrale en France au XVIII ${ }^{e}$ siècle (Paris: Honoré Champion, 1988), 35.

8. Rougemont, La Vie théâtrale en France, 38. In contrast, Joseph Harris mentions Voltaire only briefly in his recent essay on "Eighteenth-Century Theatrical Tragedy," in William Burgwinkle, Nicholas Hammond, and Emma Wilson, eds, The Cambridge History of French Literature (Cambridge: Cambridge University Press, 2011), 385-392.

9. Alexandre Joannidès, La Comédie-Française de 1680 à 1900: Dictionnaire général des pièces et des auteurs (Genève: Slatkine, 1970, reprint of 1901 first edition), Voltaire repertory; Pierre Frantz discusses this decline in “L’opéra au secours du théâtre," in François Jacob, ed., Voltaire à l'opéra (Paris: Classiques Garnier, 2011), 21-34.

10. Voltaire's novella Candide was adapted for the stage and performed at the Comédie-Française Studio-Théâtre in 2013-14. Because it was not performed on the mainstage, it is not considered to be part of the troupe's repertory (see https://www.comedie-francaise.fr/fr/evenements/candide13-14); Le Droit du seigneur was staged in Metz in 2003; L'Écossaise was staged in Paris in 2007; and Nanine was recreated in Lille in 2012 and has been performed in an array of cities. Russell Goulbourne, "Eighteenth-Century Comic Theatre," in The Cambridge History of French Literature, 378-384, 384; and Goulbourne, "Introduction," Euvres \& Critiques 33.2 (2008), 7-10. Voltaire remains controversial. A performance of Mahomet proposed in Geneva for the 1994 tri-centennial of the birth of Voltaire was cancelled when leading figures in the local Islamic community protested. In late 2005, readings of Mahomet in Saint-Genis-Pouilly and in Geneva took place under police protection, as protests took place outside. Hervé Loichemol, “Une fatwa contre Voltaire?” Le Monde, Feb. 14, 2006.

11. Émile Faguet, Voltaire (Paris: Lecène, Oudin \& Cie, 1895), 151.

12. Jay Caplan, In the King's Wake: Post-Absolutist Culture in France (Chicago: The University of Chicago Press, 1999), 156.

13. George Steiner, The Death of Tragedy (New York: Alfred A. Knopf, 1961), 190.

14. Mathé Allain, “Voltaire et la fin de la tragédie classique française," French Review 39 (1966), 384. $\Xi$

15. Voltaire's tragedies, for example, stopped appearing on the agrégation exam, used to qualify high school and university professors in France, by the middle of the twentieth century. Anne-Marie Thiesse and Hélène Mathieu, "Déclin de lâge classique et naissance des classiques: l'évolution des programmes littéraires de l'agrégation depuis 1890," Littérature 42 (1981), 89-108, 103. 16. Nicholas Cronk, ed., The Cambridge Companion to Voltaire (Cambridge: Cambridge University Press, 2009). This contrasts with the substantial attention to Voltaire's theatrical accomplishments in 
Cronk's recent biography, Voltaire: A Very Short Introduction (Oxford: Oxford University Press, 2017).

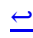

17. Geoffrey Turnovsky, “The Making of a Name: A Life of Voltaire," in The Cambridge Companion to Voltaire, 17-30, 27. In this volume, only the essay by Russell Goulbourne devotes sustained attention to his theatrical works and legacy, yet much of that essay deals with theatricality in Voltaire's oeuvre. See "Voltaire's Masks: Theatre and Theatricality," 93-108. $\leftrightharpoons$

18. In another famous example, William Shakespeare did not always dominate the Englishlanguage canon. Scholars argue that the Bard as we know him today was to no small degree an eighteenth-century invention, with the actor, director, and impresario David Garrick playing a key role in securing his legacy as England's national author. "Introduction," in Fiona Ritchie and Peter Sabor, eds., Shakespeare in the Eighteenth Century (Cambridge: Cambridge University Press, 2012). Mechele Leon, Molière, the French Revolution, and the Theatrical Afterlife (Iowa City: University of Iowa Press, 2009), 12.

19. Pierre Nora, "Between Memory and History," Representations 26 (1989), 7-24.

20. André Billaz, "Les écrivains romantiques et Voltaire" (Ph.D. thesis, Université de Lille III, 1974), vol. 1; Albert W. Halsall, Victor Hugo and the Romantic Drama (Toronto: University of Toronto Press, 1998).

21. Marvin Carlson, Voltaire and the Theatre of the Eighteenth Century (Westport, CT: Greenwood Press, 1998), 166.

22. Christian Delmas, La Tragédie de l'âge classique (1553-1770) (Paris: Seuil, 1994), 4; Frantz also writes of Romanticism as the great literary divide that "buried Voltairean tragedy," in "L'opéra au secours du théâtre," 34.

23. Quote is from Isabelle Degauque, Les Tragédies de Voltaire au miroir de leurs parodies dramatiques: d'ÆEdipe (1718) à Tancrède (1760) (Paris: Honoré Champion, 2007), 428. Taking the fact of tragedy's "deterioration" as a given, Lancaster's study of the genre sets out to determine: "Is there a steady decline, or are there ebbs and flows?" Henry Carrington Lancaster, French Tragedy in the Time of Louis XV and Voltaire, 1715-1774, 2 vols. (Baltimore: The Johns Hopkins University Press, 1950), 1:1-3, xi. Jean-Pierre Perchellet poses the question, "Faut-il, d'une certaine façon, se résoudre à admettre que la tragédie est morte en avalant le même poison que Phèdre, un jour fatal de 1677?" before answering that this was not the case. L'Héritage classique: La tragédie entre 1680 et 1814 (Paris: Honoré Champion, 2004), 347, 15. 
24. On Voltaire's connection with the decline and death of tragedy, see also Gustave Lanson, Histoire de la littérature française, 4th ed. (Paris: Hachette, 1896), 644; and Jacques Morel, La Tragédie (Paris: Armand Collin, 1970), 74. $\leftrightarrows$

25. CFRP database: based on total earnings of all plays in the royal theater's repertory for all days performed between 1720 and 1789, Zaïre was the highest earning work performed at the ComédieFrançaise, with box office receipts those evenings of 483,959.40 livres. $ヒ$

26. Alexandre Vinet, Histoire de la littérature française au dix-huitième siècle (Paris: Chez les éditeurs, 1853), 130. $\subseteq$

27. Joannidès, La Comédie-Française de 1680 à 1900, iii. $ヒ$

28. Lagrave, Le Théâtre et le public à Paris, 318-341, 597-601.

29. A later edition of Joannidès's work continues the analysis through 1920 .

30. Joannidès, La Comédie-Française de 1680 à 1900, xii-xix. Joannidès indicates every staging of a play by an author. At times, an author would be featured more than once during an evening. 31. CFRP database, Cross-Tab Browser. These three metrics were calculated using the author-n function to identify all the evenings when a work by an author was performed as the first, second, or third work of an evening. This function includes a complete listing of performance days per author, average income per performance day per author, and total income on days when an author's works were staged. It does not account for double features, however, so the total numbers of works staged by these authors would be somewhat higher. Because theater-spectators purchased entry by evening and the royal company typically performed at least a double feature, it is not possible to calculate with certainty the proportion of the box office that should be accorded to one play or one author over another on the same bill. The Comédie-Française calculated its earnings by evening. I have chosen to present the data in the same format. I would like to thank Christopher York for allowing me access to these features and for helping me to understand them. For average perevening income: Voltaire $1750 \mathrm{~L}$; Racine $1436 \mathrm{~L}$; Corneille $1340 \mathrm{~L}$; Molière $954 \mathrm{~L}$.

32. This and the following data were drawn from the CFRP database, using the author-n function. The two entries on Molière were combined. $\subseteq$

33. CFRP database, Cross-Tab Browser, author-n by decade. The numbers for Molière here and below represent the sum of both of his listings as author in the database. Dancourt's evenings brought in 397,962.53 livres while the performance evenings of Saurin, who ranked eleventh, brought in $166,760.68$ livres. $\uplus$ 
34. CFRP database, Cross-Tab Browser, author-n for 1780s: Voltaire, $925,355.20$ livres;

Beaumarchais, 632,181.15 livres.

35. CFRP database, Cross-Tab Browser, author-n1 (author of first play of the evening) for 1720-1793: Molière, 1459 performance days vs. Voltaire, 1729 performance days. Performance-day earnings: Voltaire, 4,152,559.40 L box office; Molière, 2,089,426.05 L; Racine, 1,689,915.73 L; Corneille, $1,607,773.90 \mathrm{~L} . \bullet$

36. Between 1718 and 1793, Voltaire's evenings earned a total of 4.523,964.21 livres whereas Molière's evenings earned 4,327,824.06 livres. $\subseteq$

37. Lancaster, French Tragedy in the Time of Louis XV and Voltaire, 1715-1774, I: $54 . \triangleq$

38. Joannidès, La Comédie-Française de 1680 à 1900, xviii-xix. $ヒ$

39. For much of Voltaire's career, Prosper Jolyot de Crébillon served as his principal tragic rival, viewed by some as a better poet. Voltaire deliberately adopted five of Crébillon's subjects for his own. Voltaire need not have worried, though, because with the commercial public Crébillon was not a significant competitor. From the 1720s through the early 1790s, Crébillon's works sold only a fraction of the tickets theatergoers bought to see works by Voltaire. $\triangleq$

40. CFRP database. On average, between the 1720 season and the 1789 season, evenings when tragedies were performed earned 1635.30 livres, whereas the average earning for an evening without tragedy was 1168.52 livres. $\subseteq$

41. CFRP database.

42. CFRP database. $\doteq$

43. CFRP database. Because entrances were sold for all the plays performed during an evening, this is calculated using total income for evenings when a given play was performed. Using this unweighted receipts calculation to rank the full repertory performed during a given timeframe, these were the works that emerged at the top of the list. $\subseteq$

44. CFRP database, Cross-Tab Browser, calculated using pièce-n "sum receipts" on a decade-bydecade basis, as well as for the decades 1700-1780 inclusive.

45. CFRP database, Cross-Tab Browser, calculated using Voltaire author-n un-weighted sum receipts as a percentage of the total box office income. On Voltaire's financial sway on the ComédieFrançaise, see also, in this volume, Thomas M. Luckett, “Financial Difficulties and Business 
Strategies at the Comédie-Française During the Seven Years War." Using different methods, Luckett arrives at slightly different figures.

46. Gregory S. Brown, A Field of Honor: Writers, Court Culture, and Public Theater in French Literary Life from Racine to the Revolution (New York: Columbia University Press, 2002).

47. Voltaire, Correspondence and Related Documents, ed. Theodore Besterman (Oxford: Voltaire Foundation, 1968-77), D1417 and D1662, quoted from letter to Quinault on 22 February $1738 . \uplus$ 48. Carlson, Voltaire and the Theatre of the Eighteenth Century, 9-13, 17-18, 43, 52-53. See also Lancaster, French Tragedy, 212-213.

49. Jean-Jacques Olivier, Voltaire et les comédiens interprètes de son théâtre (Paris: Société française d'imprimerie et de librairie, 1900), $116 . \triangleq$

50. Quoted in Olivier, Voltaire et les comédiens interprètes de son théâtre, 119.

51. Lauren R. Clay, Stagestruck: The Business of Theater in Eighteenth-Century France and Its Colonies (Ithaca: Cornell University Press, 2013), 152-159.

52. Olivier, Voltaire et les comédiens interprètes de son théâtre, $\mathrm{x}, 357-363$. On Voltaire's lifelong passion for acting, directing, and watching theatrical performances, see also Ronald S. Ridgway, "Voltaire as an Actor," Eighteenth-Century Studies 1:3 (Spring 1968), 261-276.

53. Perchellet, L’Héritage classique. $\triangleq$

54. James van Horn Melton, The Rise of the Public in Enlightenment Europe (Cambridge: Cambridge University Press, 2001), 177. $\subseteq$

55. On the patronage system and writers, albeit in a different genre, see Orest Ranum, Artisans of Glory: Writers and Historical Thought in Seventeenth-Century France (Chapel Hill: The Univ. of North Carolina Press, 1980), especially his chapter on Racine, 278-332. On this shift away from patronage, see Caplan, In the King's Wake, 82.

56. Voltaire, Hérode et Mariamne, Tragedie de M. de Voltaire (Paris: Noel Pissot, 1725), preface. Quoted in Carlson, Voltaire and the Theatre of the Eighteenth Century, 17. -

57. Voltaire's Correspondence, II: 324, Letter 478, Voltaire to Jean Baptiste Nicolas Formont, and 322, Letter 477, Voltaire to Pierre-Robert Le Cornier de Cideville, both from 29 May 1732. Quoted in Carlson, $43 . \longleftarrow$ 
58. Voltaire's Correspondence, III: 20, Letter 550, Voltaire to Nicolas Claude Thieriot, 24 February 1733. Quoted in Carlson, 46. $\doteq$

59. Roger Pearson, Voltaire Almighty: A Life in Pursuit of Freedom (London: Bloomsbury, 2005), 277278; Colin Duckworth, “Voltaire's L'Écossaise and Palissot's Les Philosophes: A Strategic Battle in a Major War," SVEC 87 (Oxford, 1972), 333-351; Pierre Frantz, “The Voltaire Moment, in this volume; Luckett, "Financial Difficulties and Business Strategies," also in this volume.

60. Pearson, Voltaire Almighty, 200.

61. Frantz, “The Voltaire Moment," in this volume. $\subseteq$

62. Isabelle Degauque, Les Tragédies de Voltaire au miroir de leurs parodies dramatiques, 435-444.

63. On Voltaire's influence elsewhere in Europe, notably in England, Germany, the Dutch Republic, and Italy, see Revue Voltaire 7, Echos du théâtre voltairien (2007), 13-124; and essays by Christopher Todd, Laurence Macé, and Elsa Jaubert in Euvres \& Critiques 33:2 (2008), 119-162.

64. Voltaire's works comprised 6-7\% of surviving repertories in Parma, Stockholm, and Vienna, and 4\% (equal to those of Molière) in The Hague. Rahul Markovits, Civiliser l'Europe: Politiques du théâtre français au XVIII ${ }^{e}$ siècle (Paris: Fayard, 2014), 30-31, 377. $\subseteq$

65. Harold Lawton Bruce, Voltaire on the English Stage (Berkeley: University of California Press, 1918), 134-135.

66. Bruce suggests that Voltaire's success and celebrity in France, the relative weakness of contemporary British tragedy, and the scandal that surrounded Voltaire's assaults on religion may all have have provided incentive for this literary borrowing. Bruce, Voltaire on the English Stage, 2-3. 67. Quotes from Steiner, The Death of Tragedy, 110; Delmas, La Tragédie de l'âge classique, 160. For contemporary views, compare Russell Goulbourne, "Presse périodique et critique dramatique au dix-huitième siècle: le théâtre de Voltaire dans le Journal encyclopédique," Euvres \& Critiques 33:2 (2008), 85-99. $匚$

68. One of the twentieth century's most influential designers, Raymond Loewy, articulated the ideal balance between the pleasure of surprise and the comfort of familiarity in the axiom: "most advanced yet acceptable" (MAYA). Derek Thompson, "What makes things cool," The Atlantic, JanuaryFebruary 2017, 68-72; Raymond Loewy, Never leave well enough alone (New York: Simon and Schuster, 1951), 277-283. 
69. The actors of the Comédie-Française and their audiences alike remained quite loyal to the norms of neoclassical tragedy-including the use of Alexandrine verse and respect for the unities of time, place, and action - well into the early nineteenth century. The continued attachment to these literary and cultural traditions is revealed at the troupe's production of Victor Hugo's Hernani in 1830. The first work that spurned these conventions, Hernani was initially marked by tense rehearsals, audience outbursts, and hostile press. Halsall writes of the "'battle' fought between the Romantics and their opponents during many of the play's first 39 performances in 1830." Victor Hugo and the Romantic Drama, 72-94, quote from 73.

70. Joannidès, La Comédie-Francaise, 1680 à 1900, Voltaire repertory 1800-1830. $\subseteq$

71. These were Mérope, La Mort de César, L'Orphelin de la Chine, and Zaïre. $\triangleq$

72. Joannidès, La Comédie-Francaise, 1680 à 1900, Voltaire repertory 1830-1865.

73. Martyn Lyons, "In Search of the Bestsellers of Nineteenth-Century France, 1815-1850," in Reading Culture and Writing Practices in Nineteenth-Century France (Toronto: University of Toronto Press, 2008), 34. On the publication history of Voltaire's works, see also René Pomeau, "Voltaire à la Bibliothèque nationale," in Catalogue général des livres imprimés de la Bibliothèque nationale. Auteurs. Tome CCXIV. Voltaire (Paris: Imprimerie nationale, 1978), xi-xiv. $\subseteq$

74. Emmet Kennedy, Marie-Laurence Netter, James McGregor, and Mark Olsen, eds., Theatre, Opera, and Audiences in Revolutionary Paris: Analysis and Repertory (Westport: Greenwood Press, 1996), 51-52, 162.

75. Jacqueline Razgonnikoff, “Traces de Voltaire et des représentations de ses œuvres dans les collections de la Comédie-Française," Euvres \& Critiques 33:2 (2008), 13-30; Ling-Ling Sheu, Voltaire et Rousseau dans le théâtre de la Révolution française, 1789-1799 (Brussels: Éditions de l'Université de Bruxelles, 2005), 16-20. Sheu relies on data gathered by André Tissier, which he published in Les spectacles à Paris pendant la Révolution. Répertoire analytique, chronologique et bibliographique (Geneva: Droz, 2002). $\subseteq$

76. On Voltaire's exhumation and reburial in the Pantheon, see Roger Pearson, Voltaire Almighty, 410-417. $\doteq$

77. Darrin M. McMahon, Enemies of the Enlightenment: The French Counter-Enlightenment and the Making of Modernity (Oxford: Oxford University Press, 2001), 20-21. $\leftrightarrows$

78. Lyons, "In Search of the Bestsellers," 35. $\subseteq$ 
79. Stephen Bird, Reinventing Voltaire: The Politics of Commemoration in Nineteenth-Century France (Oxford: Voltaire Foundation, 2000), 1-2. Bird draws here on Billaz, "Les écrivains romantiques et Voltaire." $\subseteq$

80. This set of texts was selected by searching the catalog of the Bibliothèque nationale de France for works with "histoire," "tableau," or "cours" and "littérature" in the title. All the works that included analysis of Voltaire were included in this sample. Published between 1798 and 1838, they include: Jean-François de La Harpe, Lycée ou Cours de littérature ancienne et moderne, 19 vols., vol. 16, no. 2 (Paris: H. Agasse, 1798-1804); Amable-Guillaume-Prosper de Barante, Tableau de la littérature française pendant le dix-huitième siècle (Paris: Colburn, 1813); Marie-Joseph Chénier, Tableau historique de l'état et des progrès de la littérature française depuis 1789 (Paris: Maradan, 1816); Pierre Hennequin, Cours de littérature ancienne et moderne (Moscow: A. Semen, 1821); Émile Vanderburch, Résumé de l'histoire de la littérature française depuis son origine jusqu'à nos jours (Paris: L. Janet, 1825); Abel-François Villemain, Cours de littérature française (Paris: Pinchon et Didier, 1830); HenriBarthélémy Aigre, Précis de l'histoire de la littérature en France, depuis les temps les plus reculés jusqu'à la Restauration (Paris: Dupont, 1835); Auguste Baron, Résumé de l'histoire de la littérature française (Paris: A. Delalain, 1835); Auguste Desprez, Histoire de la littérature française depuis son origine jusqu’à nos jours (du X $X^{e}$ au XVIII ${ }^{e}$ siècle) (Paris: Bibliothèque universelle de la jeunesse, 1837); Léon Halévy, Histoire résumée de la littérature française (Paris: D. Eymery, 1838); François Barthe, Histoire abrégée de la langue et de la littérature françaises (Paris: Hachette, 1838). $\triangleq$

81. In the nineteenth century, the phrase "C'est la faute à Voltaire, c'est la faute à Rousseau" summed up the belief that the radical ideas of the philosophes, notably Voltaire and Rousseau, were responsible for the Revolution. It emerged as early as the Revolution itself and shaped historiographical debates through the early twentieth century and beyond. See Jean-Clément Martin, La Révolution française (Paris: Le Cavalier bleu, 2008), 15-19; Michel Vovelle, The Fall of the French Monarchy, 1787-1792, trans. Susan Burke (Cambridge: Cambridge University Press, 1984), 59. 82. La Harpe, Lycée ou Cours de littérature ancienne et moderne, 16:2, 348.

83. Chénier, Tableau historique, 292.

84. Hennequin, Cours de littérature ancienne et moderne, 351.

85. Desprez, Histoire de la littérature française, quotes from 309, 305, 316-17, 306.

86. Villemain, Cours de littérature française, $272 . \subseteq$

87. Vanderburch, Résumé de l'histoire de la littérature française, $252 . \subseteq$ 
88. Barante, Tableau de la littérature française, 63. Barante's criticism is echoed in his contemporary Julien-Louis Geoffroy's Père feuilleton, 1800-1815. Valérie André, “'Quand le Père feuilleton relisait le Patriarche': le théâtre de Voltaire vu depuis la lorgnette de Julien-Louis Geoffroy," Euvres $\mathcal{Z}$ Critiques 33:2 (2008), 101-116.

89. Vanderburch, Résumé de l'histoire de la littérature française, $76 . \unlhd$

90. Aigre, Précis de l'histoire de la littérature, 250-252.

91. Villemain, Cours de littérature française, 210. $ヒ$

92. Vanderburch added, "et tout en admirant son génie et en s'éclairant de ses lumières, on éprouvait un sentiment pénible qui empêchait d'adopter sans restriction sa pensée." Résumé de l'histoire de la littérature française, 254.

93. This is observed by Barante, Tableau de la littérature française, 64; Aigre, Précis de l'histoire de la littérature, 248; Vanderburch, Résumé de l'histoire de la littérature française, 242.

94. The actors' role in determining and scheduling the repertory was confirmed in the Décret de Moscou, 1812, which largely determined the troupe's organizational structure and administrative operations for the nineteenth century. See https://www.comedie-

francaise.fr/www/comedie/media//image/ressources-numeriques/IL était une fois/cover21-cf.jpg..

95. Anonymous review in "Articles de presse concernant la parution de l'ouvrage d'Alexandre Joannidès, La Comédie-Française" (np: 1901-1920), Bibliothèque nationale de France, Arts du Spectacle. $\doteq$

96. Barante, Tableau de la littérature française, $64 . \uplus$

97. Henri Lion, Les Tragédies et les théories dramatiques de Voltaire (Paris: Hachette, 1895), vii-viii. $\subseteq$

98. Lanson, Histoire de la littérature française, $761 . \unlhd$ 